an inland region dependent on adjacent mountains and lakes for its water. Methodical irrigation might yet reclaim much that in the near future will be absorbed into desert.

S. Casson.

\section{THE BRITISH ASSOCIATION AND SCIENTIFIC RESEARCH.}

THE valuable work done for science by the research committees of the British Association is well known in the scientific world, but few people outside are familiar with its nature, extent, or influence. It is not commonly understood that all members of such committees render their services without fee of any kind, or even receive travelling expenses to attend meetings; indeed, as a general rule, a member not only gives his time and knowledge freely, but also adds somewhat to his personal expenditure. The association makes grants of a few pounds annually to some of the research committees, but others are without grants; and in many cases the chairmen and secretaries meet the necessary expenses out of their own pockets.

The committees thus represent at its highest and best united work for the promotion of natural knowledge, and their constitution could not well be improved. The subjects and members are put forward by the various sections of the association, and any grants desired have to pass the scrutiny of the Committee of Recommendations, which is made up of representatives of all the sections. The organisation is, in fact, one in which men of science themselves decide upon subjects of research, and allocate the slender funds at their disposal to aid selected inquiries and reports. Obviously, this system is both efficient and economical, and its general adoption would be in the best interests of progressive knowledge.

The amount of money which the association can allocate as grants in aid is, however, only about roool. per annum, and this has to be shared between thirty or more research committees. As other funds are now available for scientific research, it has been suggested that the association should limit its aid to committees to the payment of secretarial and like expenses, instead of attempting to provide for actual investigations by the small grants it is able to afford.

The work of the research committees has, however, been of such high value throughout the existence of the association that no one would wish to make any change which would diminish its importance; and there is not the slightest doubt that whatever funds the association has available for research will be usefully applied. The present position is clearly stated in the subjoined communication from Prof. John Perry, treasurer of the association, being mainly remarks made by him before an evening discourse on September II at the recent Bournemouth meeting of the association. No general appeal is made for funds, but it is to be hoped that wealthy benefactors will follow the example of Sir James Caird and otrers interested NO. $26 I_{3}$, VOL. IO4] in the promotion of scientific knowledge, for no more effective machinery for attaining this end could be devised than that provided by the British Association committees.

"You are aware that, after paying printing and office expenses, the funds of the British Association are devoted to scientific research. For more than eighty years we have spent more than Ioool. a vear on research, long before ordinary people had heard of research.

"Every year we form many research committees; each of them is formed of the foremost men of science of Great Britain, who receive none of the money thenselves, and their accounts for mere out-of-pocket expenses are carefully audited. These researches in the past have created some entirely new sciences, have led directly and indirectly to the creation of many new industries, and they have largely produced the world's present natural knowledge. And now to my point. Yesterday a very prominent member of the association asked me about our finances. I had to admit that even before the war we were meeting with difficulties due to the increased cost of printing and other things, that since the war we have been behindhand to the extent of more than roool. every year, and that we have never vet asked for the help of moneyed men. The only gift we have ever received from a moneyed man was a voluntary gift from Sir James Cair:l, who handed me ir,oool. at the Dundee meeting. My questioner said we ought to ask for help, and that he was willing to start a fund with a sum of roool. At this moment he does not wish to have his name mentioned.

"I need not dwell on the importance of our research work, as I feel sure that every person here who has himself done original work shares my opinion that when we limit our expenditure on research, and especially on pure scientific research, we shall begin to be a bankrupt association-bankrupt, that is, morally from the point of view of science, if not actually in the financial sense.

"The moneyed men of Great Britain are most willing to help any good object when they get proof that it really is a good object. We cannot complain of want of their help, for they did not know the facts. At the same time, the treasurer of an. association with such a record as ours does not feel happy at the prospect of begging for help."

In the two days of the meeting following that on which I made this statement, the fund was raised to a total of $1475 l$. I intend to publish in due course a list of names of donors and donations.

To illustrate by many instances (as I might) our claims as to the importance of our researches would unduly prolong this letter, and any selection of a few examples would be unrepresentative. I will cite a single illustration:-The National Physical Laboratory. the scene of researches of which the importance to the nation during the war and earlier cannot be overestimated, had its origin (if its antecedeints be traced backward) in the Kew Observatorv, which was maintained by the British Association from $I_{42}$ to 1872 , in which period the association spent some I $2,000 l$. on its upkeep.

\section{DR. JOHN AITKEN, F.R.S.}

DR. JOHN AITKEN, widely known for his unique researches in meteorology, died at Ardenlea, Falkirk, on Friday, November 14, at the ripe age of eighty years. Although he served his apprenticeship as a marine engineer, Dr. Aitken's intellectual interests drew him into the fields of 